\title{
Effects of Melatonin at Different Doses on Experimental Epilepsy Model Induced By Pentylenetetrazole
}

\author{
Pentilenetetrazol ile Oluşturulan Deneysel Epilepsi Modelinde \\ Farklı Dozlardaki Melatoninin Etkilerinin Incelenmesi \\ (1) Ferhat Şirinyıldız, (1) Rauf Onur Ek
}

Aydın Adnan Menderes University Faculty of Medicine, Department of Physiology, Aydın, Turkey

Keywords

Antioxidant, experimental epilepsy, melatonin, oxidative stress, PTZ, rat

Anahtar Kelimeler

Antioksidan, deneysel epilepsi, melatonin, oksidatif stres, PTZ, sıçan

Received/Geliş Tarihi : 19.02.2021

Accepted/Kabul Tarihi : 23.03.2021

doi:10.4274/meandros.galenos.2021.49358

Address for Correspondence/Yazışma Adresi: Ferhat Şirinyıldız MD,

Aydın Adnan Menderes University Faculty of Medicine, Department of Physiology, Aydın, Turkey

Phone : +90 5076627799

E-mail : ferhat.sirinyildiz@gmail.com

ORCID ID: orcid.org/0000-0001-8800-9787

(C) Meandros Medical and Dental Journal, Published by Galenos Publishing House.

This is article distributed under the terms of the Creative Commons Attribution NonCommercial 4.0

International Licence (CC BY-NC 4.0).

\begin{abstract}
Objective: This study aimed to evaluate the effect of melatonin (MEL) treatment on rats with experimental epilepsy induced by pentylenetetrazole (PTZ). Changes in the control, epilepsy and two treatment groups (25 mg/kg and $100 \mathrm{mg} / \mathrm{kg}$ ) were monitored as intragroup and intergroup changes.

Materials and Methods: Forty male Wistar albino rats (12-14 weeks old) were divided into control, PTZ, MEL25 and MEL100 groups, with 10 rats in each group. Only solvent was injected in the control group, and PTZ at a dose of $35 \mathrm{mg} / \mathrm{kg}$ was administered intraperitoneal 12 times in a total of 23 days in the PTZ group. MEL25 and $100 \mathrm{mg} / \mathrm{kg}$ were administered in the MEL25 and MEL100 groups, respectively. Parameters tested during and after the experiment were behavioural tests (elevated plus maze), biochemical tests in brain tissue [after decapitation; malondialdehyde (MDA), catalase (CAT), superoxide dismutase (SOD), total antioxidant status (TAS) and total oxidant status (TOS)] and epileptic seizure severity scale scores (every injection day).

Results: Significant differences were observed among the epilepsy, control and treatment groups, except for the hiding times, seizure scores and biochemical tests $(p<0.05)$. As a result of biochemical tests applied to the homogenised brain tissue after decapitation, dose-dependent results were found to be related to the different doses of MEL applied in MDA, CAT, SOD, TAS and TOS levels $(p<0.05)$.

Conclusion: In this study, MEL showed a protective and healing role against physiological changes caused by experimental epilepsy, through its capacity to reduce oxidative damage and increase antioxidant potency.
\end{abstract}

Öz

Amaç: Bu çalışmada, pentilenetetrazol (PTZ) ile indüklenen deneysel epilepsi oluşturulmuş sıçanlarda melatonin (MEL) tedavisinin etkisinin değerlendirilmesi amaçlanmıştır. Kontrol grubu, epilepsi grubu ve iki tedavi grubundaki değişiklikler $(25 \mathrm{mg} / \mathrm{kg}$ ile $100 \mathrm{mg} / \mathrm{kg}$ ) grup içi ve gruplar arası olarak değerlendirilmiştir.

Gereç ve Yöntemler: Kırk adet erkek Wistar albino sıçan (12-14 haftalık) 4 farklı gruba (kontrol, PTZ, MEL25, MEL100) ayrıldı. Kontrol grubuna sadece çözgen enjekte edildi ve PTZ grubuna $35 \mathrm{mg} / \mathrm{kg}$ dozunda PTZ intraperitoneal toplam 23 gün süresince $12 \mathrm{kez} \mathrm{günaşırı} \mathrm{uygulandı.} \mathrm{Melatonin,} \mathrm{MEL25} \mathrm{grubu} \mathrm{için} 25 \mathrm{mg} / \mathrm{kg}$ ve MEL100 grubu için $100 \mathrm{mg} / \mathrm{kg}$ uygulandı. Deney sırasında ve sonrasında test edilen 
parametreler davranış testi (yükseltilmiş artı labirent), beyin dokusunda biyokimyasal testler [dekapitasyon sonrası; malondialdehit (MDA), katalaz (CAT), süperoksit dismutaz (SOD), toplam antioksidan durumu (TAS) ve toplam oksidan durumu (TOS)] ve epileptik nöbet şiddeti ölçek skorları (her enjeksiyon günü) idi.

Bulgular: Epilepsi grubu ile kontrol ve tedavi grupları arasında kaçıs ve saklanma süreleri, nöbet skorları ve biyokimyasal testler açısından anlamlı farklııklar bulundu $(p<0,05)$. Dekapitasyon sonrası homojenize beyin dokusuna uygulanan biyokimyasal testler sonucunda MDA, CAT, SOD, TAS ve TOS düzeylerinde farklı dozlarda uygulanan MEL ile ilgili doza bağlı iyileşmeler saptandı $(p<0,05)$. Sonuç: Çalışma sonucunda MEL'nin deneysel epilepsinin neden olduğu fizyolojik değişikliklere karşı koruyucu ve iyileştirici rolü olduğu ve oksidatif hasarı azaltıcı ve antioksidan potansiyeli artırıcı etki gösterdiği tespit edilmiştir.

\section{Introduction}

Epilepsy is a neurological disorder, characterized by unpredictable seizures occurring repeatedly. Epileptic seizures affect nearly 50 million people, approximately $\% 1$ of the world's population (1). These seizures are associated with cognitive and behavioral disorders that have a significant impact on patients' quality of life. Epileptic seizures may cause cognitive function defects. Abnormal electrical activities of neurons cause changes on behavioral and cognitive processes (2). Patients affected by epileptic seizures often show impaired spatial memory and emotional learning. These changes may be also associated with different comorbidities such as anxiety, sleep, disorders and depression $(3,4)$.

Oxidative stress has an important role at epileptic stage. Reactive oxygen derivatives are mainly responsible for oxidative stress. These can be oxygencentered radicals that have unpaired electrons or covalent molecules (such as hydrogen peroxide) (5). Reactive oxygen species; $\mathrm{H}_{2} \mathrm{O}_{2}, \mathrm{O}_{2}^{-}, \mathrm{OH}^{-}$; are produced during and after epileptic seizures, may contribute brain damage. The brain is vulnerable to free radical damage due to its high oxygen consumption, high lipid content, and also less antioxidant enzymes compared to other tissues. There are several experimental models that show the relation between epileptic seizures and oxidative damages. Moreover, excessive free radical production is associated with injury to cell structures, including lipid structure disruption of cells, enzyme inactivation, and DNA damage (6).

There are various experimental models to find out the mechanisms of acute and chronic epilepsy. For these models of epilepsy are induced by administration of convulsive drugs or electrical stimulation. It is possible to initiate partial and generalized seizures by using various chemicals, such as pentylenetetrazole (PTZ), penicillin, kainic acid, etc.
(7). One of the most common experimental model is a chemical inducing method, the PTZ-induced seizures (8). PTZ is a tetrazole compound that is an agent for generalized tonic clonic epileptic seizure induction. It was demonstrated that PTZ affects the disruption of gamma amino butyric acid (GABA) (9). The formation of free radicals has been shown during and after seizures in PTZ-induced models. Especially in chronic PTZ exposure, formation of free radicals significantly increased and oxidative stress damage was found to occur. The PTZ model is a useful model for detecting post-seizure dysfunctions that serve as a screen for possible treatments, offering the possibility to study animal models for cognitive, physical and emotional deficits in human epilepsy (10).

Melatonin (MEL) is produced by the pineal gland and is an indolamine derivative of serotonin. It has long been described as a reproductively active hormone that regulates the sexual physiology seasonally (11). MEL has been shown to have various antioxidant and anticonvulsive effects on the central nervous system of mammals $(12,13)$. Experiments reported that MEL exert proconvulsant effects in humans especially via protecting cortical GABA levels (13). As an antioxidant, MEL is effective in protecting nuclear DNA, membrane lipids, and cytosolic proteins from oxidative damage. It is also shown that MEL has role to suppress brain excitability and prevent seizures. MEL blocks glutamatergic-dependent brain excitability and thus functions as an anti-excitotoxic compound $(5,13)$.

The objective of the present study was to evaluate the effects of different doses of MEL application on the seizure levels and oxidative status of the brain tissues in a rat model of PTZ-induced epilepsy. In addition, together with biochemical and histological evaluations, it was aimed to determine the behavioral changes caused by PTZ with the elevated plus maze test. 


\section{Materials and Methods}

Drugs and chemicals: PTZ and MEL were purchased from Sigma-Aldrich (St. Louis, MO, USA). The dose of PTZ and MEL were calculated from the corresponding experimental doses (13-15). All injections and experiments were performed between July to August, at the time from $02.00 \mathrm{pm}$ to $07.00 \mathrm{pm}$.

Animals: Forty male Wistar Albino rats $(220 \pm 20$ $\mathrm{g}$ in weight) were maintained under controlled conditions, including 12-hour (h) light/dark cycle, 22$24{ }^{\circ} \mathrm{C}$ temperature, and appropriate humidity, with laboratory chow and water provided ad libitum. All animal experiments were carried out in accordance with the approval of the Animal Use Adnan Menderes University Ethical Committee (decision no: 64583101/2014/022, date: 27.02.2014).

Groups: The animals were acclimatized for 15 days before starting experiments. Forty rats were randomly divided in four groups with ten animals in each group: Control: Sham-control, PTZ: PTZepileptic, $35 \mathrm{mg} / \mathrm{kg}$ PTZ administrated PTZ+MEL25: $25 \mathrm{mg} / \mathrm{kg}$ MEL treatment group before the induction of epileptic seizures by the injection of $35 \mathrm{mg} / \mathrm{kg} \mathrm{PTZ,}$ PTZ+MEL100: 100 mg/kg MEL treatment group before the induction of epileptic seizures by the injection of $35 \mathrm{mg} / \mathrm{kg}$ PTZ.

Experimental procedures: After acclimation, experiments started with the first injection of PTZ and finished after the $12^{\text {th }}$ injection of PTZ on the $23^{\text {rd }}$ day. MEL, purchased in powder form, was prepared to be dissolved in $10 \%$ dimethyl sulfoxide (DMSO) and given at the appropriate dose $(16,17)$. Control group (Shamcontrol group) received an intraperitoneal (i.p.) injection of $10 \%$ DMSO solution prepared in distilled water every other day ( $3.5 \mathrm{~mL} / \mathrm{kg}, 12$ injections total). PTZ group (PTZ-epileptic group) was administered with PTZ ( $35 \mathrm{mg} / \mathrm{kg}$, i.p., 12 injections total) every other day. MEL25 group (PTZ+MEL25 group) was injected by $25 \mathrm{mg} / \mathrm{kg}$ MEL half an $\mathrm{h}$ before the administration of PTZ (35 mg/kg PTZ, 25 mg/kg MEL, i.p., 12 injections total). MEL100 group (PTZ+MEL100 group) was injected by $100 \mathrm{mg} / \mathrm{kg} \mathrm{MEL}$ half an $\mathrm{h}$ before the administration of PTZ ( $35 \mathrm{mg} / \mathrm{kg}$ PTZ, $100 \mathrm{mg} / \mathrm{kg} \mathrm{MEL}$, i.p., 12 injections total). Groups were monitored for 1 $\mathrm{h}$ after PTZ injection by 2 blind-researchers. At the end of experiments rats were anesthezied by ketamine (80 $\mathrm{mg} / \mathrm{kg}$ ) and xylazine $(4 \mathrm{mg} / \mathrm{kg})$ intraperitoneally and sacrificed by decapitation. The brains were collected for biochemical measurements.

Epileptic seizures monitoring: Animals were continuously monitored for $12 \mathrm{~h} /$ day at light period for 7 days before experiments and 23 days during experiments. Seizure severity was scored using the Racine scale (18) by direct observation and indirect observation based on the video records. Recordings were analyzed and scored by two independent, blind investigators. The scores of Racine scale are; 0 for no convulsive behavior; 1 for myoclonic jerks; 2 for bilateral forelimb clonus lasting less than $3 \mathrm{~s}$; 3 for bilateral forelimb clonus lasting more than $3 \mathrm{~s}$; 4 for tonic-clonic seizure under 10 minutes (min); 5 for tonic-clonic seizure over $10 \mathrm{~min}$; 6 for death. At the end of the experiments, the scores from both investigators were collected by another researcher and the medians of these scores were used as the final scores.

Elevated plus maze test: The elevated $T$ maze was made of transparent glass and consisted of two open arms, $(50 \times 10 \mathrm{~cm})$ two enclosed arms $(50 \times 10 \times 40$ $\mathrm{cm})$ and a central platform $(10 \times 10 \mathrm{~cm})$. The plusmaze was $50 \mathrm{~cm}$ above the floor. The researcher observed elevated plus-maze and recorded the data by chronometer behind the closed arms. Pellow's (19) method was used as experimental procedure. Rats were placed individually in a new cage that had same conditions as home cage for $5 \mathrm{~min}$ before the test. Every rat was then placed in the center of the plus-maze one by one, that was facing one of the closed arms. After familiarization repeats to test platform, for experiment, measurements were taken by a researcher. Main object was the time spent on open arm enclosed arms. A rat was taken to have entered an arm when all four legs were on the arm. To measure time spent on enclosed arms, open arm time period was recorded and difference to total time was calculated. At the end of the test, the total measurement time for every rat was recorded. The duration of analysis time was kept constant as 5 min300 seconds in accordance with the protocol in the literature (20).

Tissue samples: On the last day of experiment, 90 min after last PTZ administration, the animals were killed by decapitation and their brains were dissected. Ten milliliters of $140 \mathrm{mM} \mathrm{KCl}$ solution/gram of tissue were added and all tissue were then homogenized 
in a motor-driven homogenizer (Ultra Turrax, IKAWERKE, Germany) (21). Then samples centrifuged at $12,000 \mathrm{rpm}$ for $10 \mathrm{~min}$. The supernatant was used for biochemical measurements.

Determination of brain lipid peroxidation: Lipid peroxidation was determined in tissue samples by measuring malondialdehyde (MDA) levels as thiobarbituric acid reactive substances (TBARS) (22). Trichloroacetic acid and TBARS reagent were added to the tissue homogenates, then mixed and incubated at $100{ }^{\circ} \mathrm{C}$ for $60 \mathrm{~min}$. After cooling on ice, the samples were centrifuged at $3000 \mathrm{rpm}$ for $20 \mathrm{~min}$ and the absorbance of the supernatant was read at 535 $\mathrm{nm}$. MDA levels were calculated from the standard calibration curve using tetraethoxypropane and expressed as nmol/gr tissue.

Determination of brain superoxide dismutase (SOD) activity: SOD activity was determined according to the method of Sun et al. (23). Tissue should be perfused with $150 \mathrm{mM} \mathrm{KCl}$ to remove any red blood cells. The tissue samples homogenized in ice-cold 0.1 $\mathrm{M}$ Tris $/ \mathrm{HCl}, \mathrm{pH} 7.4$ containing $0.5 \%$ Triton X-100, 5 $\mathrm{mM} \beta-\mathrm{ME}, 0.1 \mathrm{mg} / \mathrm{mL}$ phenylmethylsulfonyl fluoride. After centrifugation the supernatant contains total SOD activity from cytosolic and mitochondria. The absorbance of the supernatant was read at 450 $\mathrm{nm}$. SOD activity was given as miliunits per milliliter homogenate $(\mathrm{mU} / \mathrm{mL})$.

Determination of brain catalase (CAT) activity: CAT activity was assayed according to the method described by Maehly and Chance (24), based on the disappearance of $\mathrm{H}_{2} \mathrm{O}_{2}$ at $240 \mathrm{~nm}$. $10 \mu \mathrm{L}$ of homogenate was added to $180 \mu \mathrm{L}$ of $20 \mathrm{mM}$ potassium phosphate buffer $\mathrm{pH}$ 7.2. Subsequently, $10 \mu \mathrm{L}$ of $5 \mathrm{mM} \mathrm{H}_{2} \mathrm{O}_{2}$ was added and absorbance was immediately recorded every $30 \mathrm{~s}$ for $10 \mathrm{~min}$, using a ELX800 ${ }^{\mathrm{TM}}$ Microplate Reader (Biotek Instruments Inc. Winooski, USA). One CAT unit was defined as one $\mu \mathrm{mol}$ of hydrogen peroxide consumed per min and the specific activity was calculated as CAT $\mathrm{mU} / \mathrm{mL}$ homogenate.

Total antioxidant status (TAS) and total oxidant status (TOS) levels: TAS measurement is based on the principle that the color formed by the 2,2'-azinobis (3-ethylbenz-thiazoline-6-sulfonic acid) (ABTS) radical changes with the antioxidants in the samples added to the medium, and the measurement was performed using the biochemical kit. Antioxidants in the sample reduce dark blue-green colored ABTS radical to colorless reduced ABTS form. The change of absorbance at $660 \mathrm{~nm}$ is related with total antioxidant level of the sample. In order to perform TOS measurement, after decapitation, the brain tissue was homogenized as indicated. Oxidants present in the sample oxidize the ferrous ion-chelator complex to ferric ion. The ferric ion makes a colored complex with chromogen in an acidic medium. The color intensity, which can be measured spectrophotometrically, is related to the total amount of oxidant molecules present in the sample. The assay is calibrated with hydrogen peroxide and the results are expressed in terms of micromolar hydrogen peroxide equivalent per liter ( $\mu \mathrm{mol} \mathrm{H}_{2} \mathrm{O}_{2}$ Equiv./L).

\section{Statistical Analysis}

All data were analyzed by GraphPad 7 statistical program (GraphPad Software, Inc., CA, USA). Elevated Plus Maze durations and Epileptic Seizure scores were compared by the Kruskal-Wallis non-parametric test-Dunn's multiple comparison test and other parameters were compared by One-way ANOVADunnet's multiple comparison test. D'agostino pearson normality test was applied to determine normality. Values represent the mean \pm standard deviation of $n=10$ animals per group. $n s=$ non-significant, $p>0.05$, ${ }^{*} p \leq 0.05, * * p \leq 0.01, * * * p \leq 0.001$. The control, MEL25 and MEL100 groups were compared with the PTZ group, and the treatment groups were compared among themselves. In the graphs, the arrows at the top show this comparison. In group comparisons, PTZ group was considered as the focus of comparison. The deteriorations in the control group and changes in the treatment groups were examined in this way.

\section{Results}

Epileptic seizure scores: To estimate the severity of seizures, Racine scale was used. Seizure severity was grouped in 3 ways: 1 . No effect, 2 . Minimal clonic seizure (MCS), 3. Generalized tonic-clonic seizure (GTCS). For 23 days, 12 injections, animals from the groups were monitored and scored based on Racine scale by two blind researchers. 0 severity for Racine scale means no effect, from 1 to 3 severity for Racine scale means MCS and $4^{\text {th }}$ and $5^{\text {th }}$ severity for Racine scale means GTCS. There was no rat to die as a result of PTZ injection, so no animal was grouped 6 severity for Racine scale. For the first injection of PTZ there is no difference significantly between the groups since 
$35 \mathrm{mg} / \mathrm{kg}$ PTZ is not acute dosage for rats to show difference. PTZ injections were associated with both minimal and generalized seizure incidences in all PTZexposed groups. For the first MEL injection, there was no significantly different alteration in between the groups (Figure 1). However after first time, MEL injections for both doses showed a protective effect in PTZ-induced seizures. It was showed that, without treatment, PTZ-induced rats had severe GTCSs. However, the animals that were treated by MEL showed MCS with low severity. $100 \mathrm{mg} / \mathrm{kg} \mathrm{MEL}$ treatment had a protective effect on rats, to increase the MCS and GTCS both for severity and latency compared to the PTZ group and MEL25 group. $25 \mathrm{mg} /$ $\mathrm{kg}$ MEL treatment had also positive effects to protect from seizures; however compared to MEL100 group, MEL25 had lower significance against PTZ group. Total results of epileptic seizure scores are shown in Table 1 and summarized in Figure 1 and Figure $2 a$ and $2 b$.

Biochemical results: In order to investigate whether the antioxidant properties of MEL against PTZ were mediated by an increase in antioxidant

\begin{tabular}{|l|l|}
\hline \multicolumn{2}{|l|}{ Table 1. Seizure score medians between groups } \\
\hline & Seizure scores (Median) \\
\hline Control & 0.0 \\
\hline PTZ & $4.036 \pm 0.062$ \\
\hline MEL25 & $2.600 \pm 0.121$ \\
\hline MEL100 & $1.618 \pm 0.121$ \\
\hline PTZ: Pentylenetetrazole, MEL: Melatonin \\
\hline
\end{tabular}

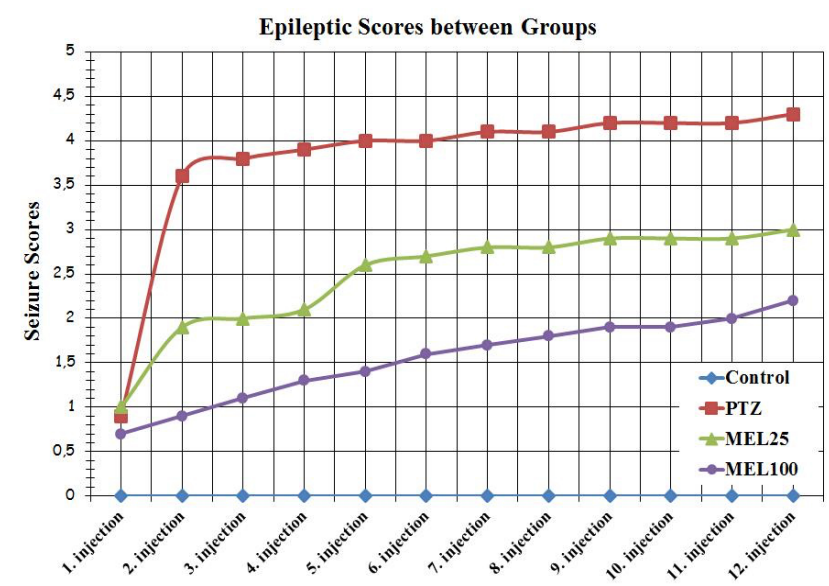

Figure 1. Effects of different doses of melatonin on total epileptic seizures

PTZ: Pentylenetetrazole, MEL: Melatonin enzymes, SOD and catalase activities were measured. Biochemical results; MDA levels, SOD activities and CAT activities are shown in Table 2.

MDA levels: There were significantly increased MDA levels the animals that were grouped as PTZ compared to control group animals. Administration of $25 \mathrm{mg} / \mathrm{kg}$ MEL did make a significant difference in brain MDA concentrations between the MEL25 and PTZ groups $(p<0.05)$. MEL100 group, that was administrated $100 \mathrm{mg} / \mathrm{kg}$ MEL, had more significant difference compared MEL25 group against PTZ group. The results are summarized in Figure 3 . The MDA levels in the brains of PTZ group were observed to

Epileptic Seizure Scores (Excluding $1^{\text {st }}$ injection)

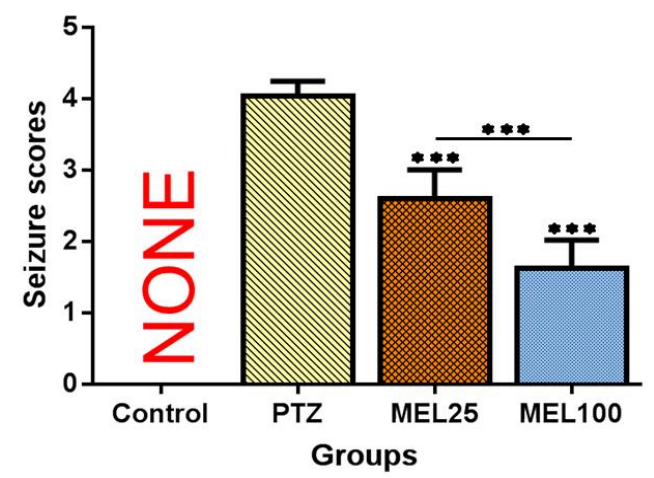

Figure 2a. Effects of different doses of melatonin on total epileptic seizures except $1^{\text {st }}$ day. Group comparisons are: PTZ/ MEL25; ***, PTZ/MEL100; ***, MEL25/MEL100; ***

PTZ: Pentylenetetrazole, MEL: Melatonin

$1^{\text {st }}$ injection Epileptic Seizure Score

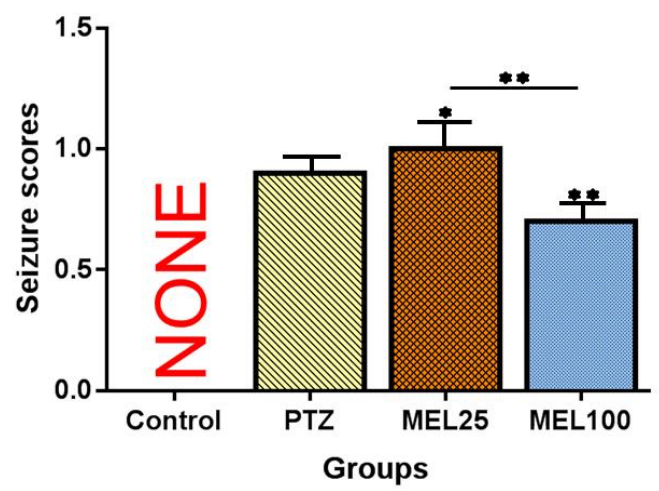

Figure 2b. Effects of different doses of melatonin on first day epileptic seizures. Group comparisons are: MEL25/PTZ; *, PTZ/ MEL100; **, MEL25/MEL100; **

PTZ: Pentylenetetrazole, MEL: Melatonin 
be significantly increased in comparison to that of control group. It was also observed that, a significant decrease of the MDA levels in comparison to that of PTZ group were more prominently in MEL100 group.

SOD activity: SOD activity was found significantly low at PTZ group compared to control, MEL25 and MEL100 groups $(p<0.05)$. As a result of treatment with 25 and $100 \mathrm{mg} / \mathrm{kg} \mathrm{MEL}$, SOD activities are found significantly higher compared to PTZ group $(p<0.05)$. There is also dose dependent difference between MEL25 and MEL100 groups, demonstrating that MEL administration supports antioxidant activity in a dosedependent manner. The results are summarized in Figure 4.

CAT activity: The results revealed that CAT activity was observed to be decreased in the PTZ group in comparison to that of control group. The results of MEL25 and MEL100 groups demonstrated that MEL has supported the CAT activity in the brain in a

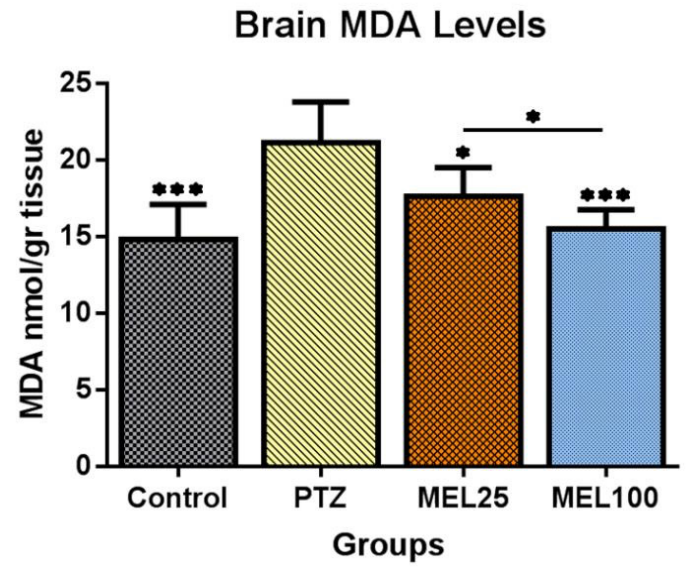

Figure 3. The effect of melatonin administration on the MDA level, as a marker of lipid peroxidation in the rat brain. Group comparisons are: Control/PTZ; ***, PTZ/MEL25; ***, PTZ/ MEL100 ***, MEL25/MEL100; ***

PTZ: Pentylenetetrazole, MEL: Melatonin, MDA: Malondialdehyde dose-dependent manner. The highest CAT activity was observed to be in the MEL100 group, while the CAT activity of MEL25 group were observed to be higher than that of PTZ group, although not as higher as MEL100 group. The results are summarized in Figure 5.

TAS and TOS levels: The highest antioxidant content was observed in the control group, where there was a decreased antioxidant content in the PTZ group and the antioxidant power was increased in the MEL treatment groups (Figure 6a). The highest oxidative stress content was observed in the PTZ group, and the oxidant content of the MEL treatment groups decreased in dose-dependent manner, where the oxidant content was the least in the control group (Figure 6b).

Behavioral results: To estimate behavioral results, epileptic seizure monitoring and elevated plus maze tests were done. Elevated plus maze test: Animals that were only exposed to PTZ, had shown significantly

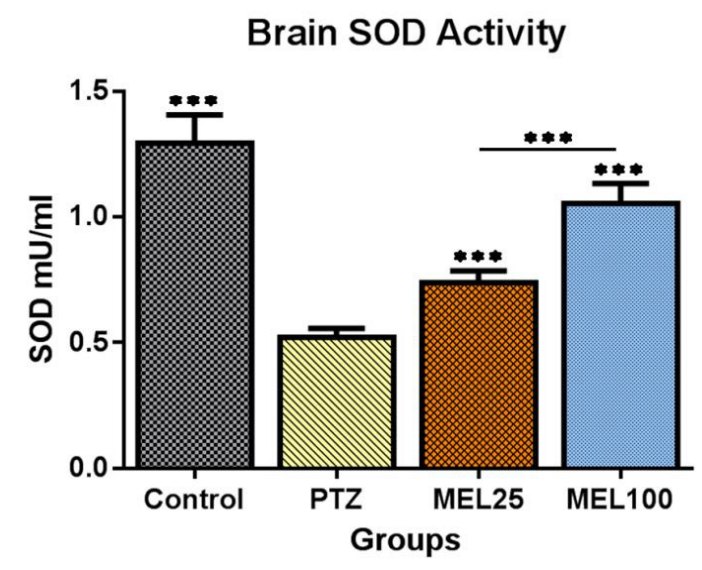

Figure 4. The effect of melatonin administration on the activity of the antioxidant enzyme SOD in the rat brain. Group comparisons are: Control/PTZ; ***, PTZ/MEL25; ***, PTZ/ MEL100; ***, MEL25/MEL100; ***

PTZ: Pentylenetetrazole, MEL: Melatonin, SOD: Superoxide dismutase

\begin{tabular}{|c|c|c|c|c|c|}
\hline & $\begin{array}{l}\text { MDA } \\
\text { (nmol/gr tissue) }\end{array}$ & SOD $(\mathrm{mU} / \mathrm{mL})$ & CAT (mU/mL) & $\begin{array}{l}\text { TAS } \\
(\mathrm{mM})\end{array}$ & $\begin{array}{l}\text { TOS } \\
\left(\mu \mathrm{mol} \mathrm{H}_{2} \mathrm{O}_{2}\right)\end{array}$ \\
\hline Control & $14.81 \pm 1.145$ & $1.292 \pm 0.040$ & $0.718 \pm 0.035$ & $1.73 \pm 0.085$ & $19.42 \pm 0.32$ \\
\hline PTZ & $21.10 \pm 0.948$ & $0.520 \pm 0.013$ & $0.516 \pm 0.018$ & $1.31 \pm 0.045$ & $29.84 \pm 0.03$ \\
\hline MEL25 & $17.62 \pm 0.665$ & $0.736 \pm 0.017$ & $0.630 \pm 0.014$ & $1.53 \pm 0.016$ & $25.19 \pm 0.18$ \\
\hline MEL100 & $15.49 \pm 0.441$ & $1.053 \pm 0.028$ & $0.686 \pm 0.014$ & $1.70 \pm 0.098$ & $20.86 \pm 0.16$ \\
\hline
\end{tabular}


low time spending at open arms and group escape time was lower against MEL groups. Animals that were injected MEL had spent more time at open arms compared to PTZ group and dose depended MEL effect had shown. Total escape time scores for control, PTZ, MEL25 and MEL100 groups are shown in Table 3 and summarized Figure 7 and Figure 8, and MEL100 group score is much more similar to control group compared to the other groups.

\section{Discussion}

In the present study, we investigated the anticonvulsant activity of dose dependent $\mathrm{MEL}$

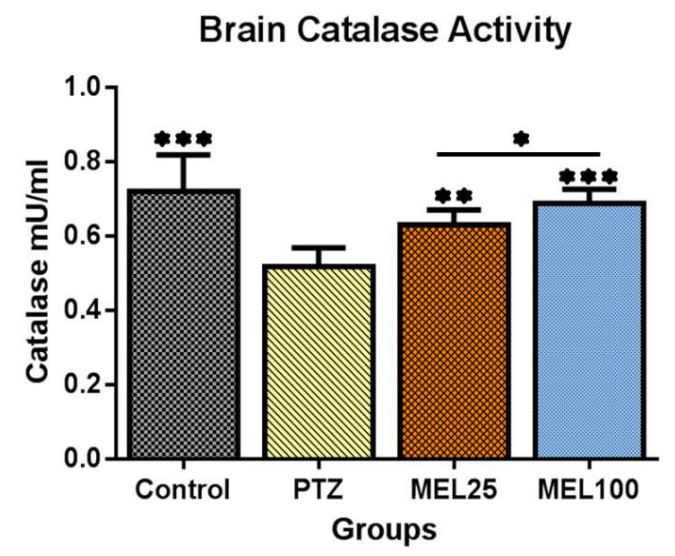

Figure 5. The effect of melatonin administration on the activity of the antioxidant enzyme Catalase in the rat brain. Group comparisons are: Control/PTZ; ***, PTZ/MEL25; **, PTZ/ MEL100; ***, MEL25/MEL100; *

PTZ: Pentylenetetrazole, MEL: Melatonin

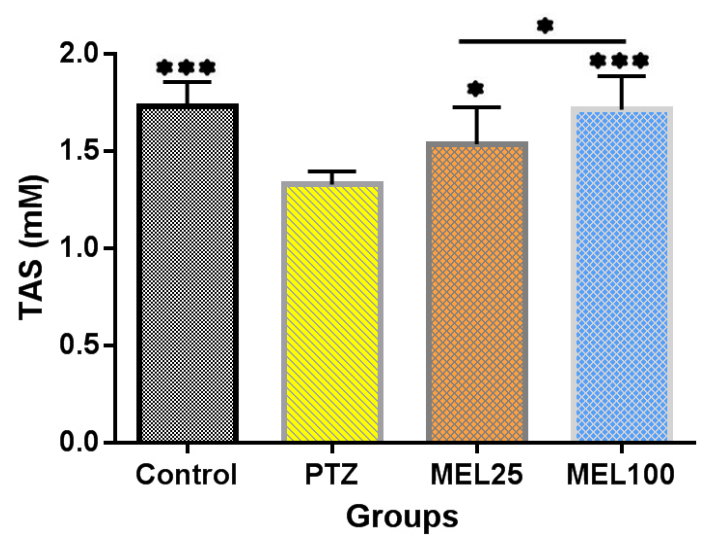

Figure 6a. Comparison of "Cerebral Total Antioxidant Concentration" between groups. Group comparisons are: Control/PTZ; ***, PTZ/MEL25; *, PTZ/MEL100 ***, MEL25/ MEL100; *

PTZ: Pentylenetetrazole, MEL: Melatonin, TAS: Total antioxidant status administration against to oxidative epileptic seizure severity that induced to PTZ. Many academic researches showed that there are different experimental models to create similar seizures that like human epilepsy (25-27). Our study also

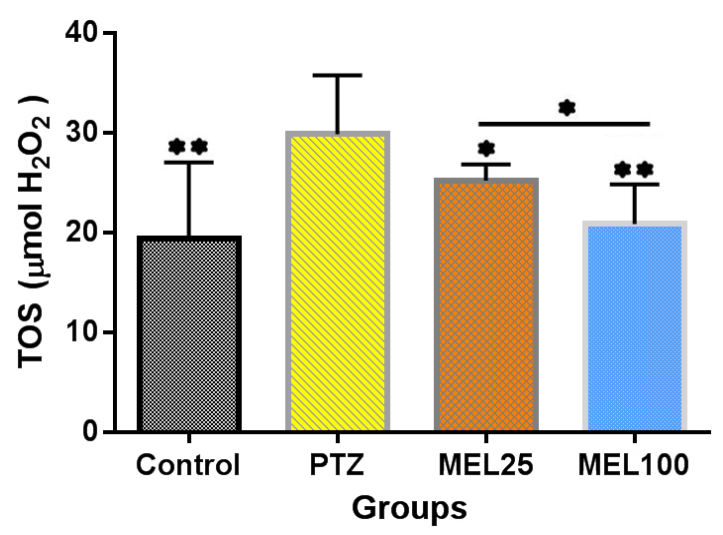

Figure 6b. Comparison of "Cerebral Total Oxidant Content" between groups. Group comparisons are: Control/PTZ; **, PTZ/ MEL25; *, PTZ/MEL100 **, MEL25/MEL100; *

PTZ: Pentylenetetrazole, MEL: Melatonin, TOS: Total oxidant status

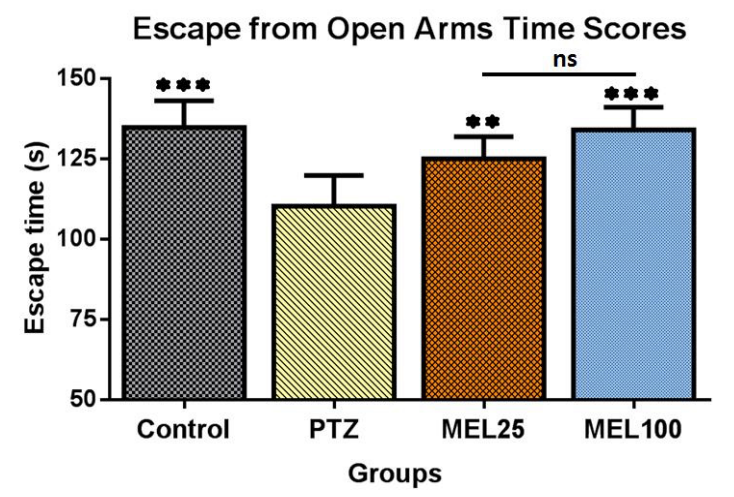

Figure 7. Effects of different doses of melatonin on exploratory and anti-hiding behavior in rats given a 5-minutes test in the elevated plus-maze. These results represent total time spent of open arms. Group comparisons are: Control/PTZ; ***, PTZ/ MEL25; **, PTZ/MEL100; ***, MEL25/MEL100; ns

PTZ: Pentylenetetrazole, MEL: Melatonin, ns: Not significant

\begin{tabular}{|l|l|}
\hline \multicolumn{2}{|l|}{ Table 3. Escape times of rats between groups } \\
\hline Control & Escape time (s) \\
\hline PTZ & $134.7 \pm 2.633$ \\
\hline MEL25 & $110.3 \pm 3.008$ \\
\hline MEL100 & $124.9 \pm 2.218$ \\
\hline PTZ: Pentylenetetrazole, MEL: Melatonin \\
\hline
\end{tabular}


Hiding at Enclosed Arms Time Scores

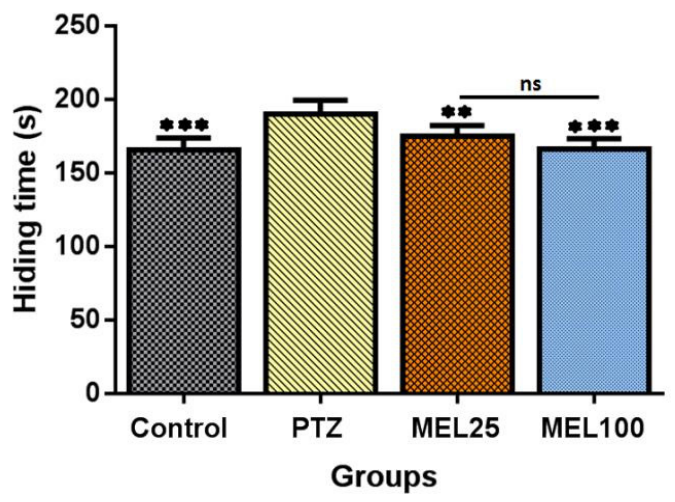

Figure 8. Effects of different doses of melatonin on hiding behavior at enclosed arms in rats given a 5-minutes test in the elevated plus-maze. These results represent total time spent of enclosed arms. Group comparisons are: Control/PTZ; ***, PTZ/ MEL25; **, PTZ/MEL100 ***, MEL25/MEL100; ns

PTZ: Pentylenetetrazole, MEL: Melatonin

showed that, $35 \mathrm{mg} / \mathrm{kg}$ PTZ injection created tonicclonic seizures and this created different conditions; like oxidative damage, prevent normal activity of antioxidant system and depressive behaviors of animals. Uyanikgil et al. (15), Wada and Fukuda (28) and Frantz et al. (6) demonstrated these effects on animals that are manipulated by injected PTZ.

Novel studies demonstrated that, MEL has anticonvulsive activity on the experimental animals that were manipulated and showed epileptic seizures induced by penicillin, pilocapine, kainite or PTZ $(29,30)$. However, most studies demonstrated positive effects of MEL on acute epileptic attacks, some studies showed positive results on chronic epileptic seizures. Different from the other researches, our study focused on both chronic period and different doses of $\operatorname{MEL}(10,12,13,26)$. As a result of that, we uncovered antiepileptic activity of MEL, during ongoing PTZ injections and after decapitation biochemical results supported these results. Our results showed that, without any protective agents, PTZ group seizure scores are higher than dos dependent MEL administrated groups. Choopankareh et al. (31) also recorded similar results that supported our study.

Previous studies showed the results of increased free radical levels during the seizures $(5,31)$. Similarly, we demonstrated an increase in MDA levels at
PTZ administrated group. On the other hand, both low and high dose MEL groups showed decrease in MDA levels, especially high dose MEL had more effective results. Reactive oxygen species, like superoxide anions, hydroxyl radicals, and hydrogen peroxide cause oxidative damage (32) and during the seizures increased oxidative damage create different neurological and psychiatric problems, like neuronal cell death, depression, anxiety etc. (33).

In this study, animals from PTZ group, without administrated MEL, resulted in a significantly decrease in time spent to open arms at the test of elevated plus maze. On the other hand, with MEL treatment, time spent to open arms increased. Pellow et al. (19) who validated plus-maze as a measure of anxiety in the rat, demonstrated that, anxiety significantly reduces exploratory behaviors in open arms, since decreased time spent in open arms and increased time spent in enclosed arms are defined as high anxiety for rats. Wada and Fukuda (28) also found significantly decreasing of spent time open arms the animals that didn't take any drugs except PTZ.

It is known that, ROS both play role to disrupt physiological stages of organism and prevent to produce antioxidant system enzymes $(34,35)$. In a result of this condition, higher MDA levels are estimated to reduce antioxidant activity. Eun et al. (36) demonstrated that, in epileptic cerebral cortices, down regulated SOD transcription occurred and protein level of SOD was lower than the samples that were not from epileptic cerebrums. Previous studies showed that, CAT activity is an essential parameter to identify effective function of antioxidant systems $(37,38)$. In this study both SOD and CAT activity were found higher in MEL administrated groups. In addition, high MEL administrated group had significantly higher results than low MEL administrated group.

Oruc et al. (39) compared the TAS and TOS results with some other parameters such as HIF 1alpha after crokin treatment in cerebral ischemia, and found that TOS levels increased and TAS levels decreased in the brain tissue of cerebral ischemic rats, while crocin treatment was shown opposite effect. Koksal et al. (40) found that the increased TOS level as a result of ischemia decreased with the MEL treatment and increased TAS levels were found in rats treated with MEL. In our study, MEL caused increased TOS levels in the brain tissues of rats group in the PTZ- 
induced epileptic seizures, and decreased TAS levels to increase. Statistically significant dose dependent effect was evaluated.

\section{Conclusion}

In conclusion, our study showed that, MEL has dose depended therapeutic effects on epileptic seizure determination. We found that, different doses of MEL support antioxidant activities capacities and decrease lipid peroxidation. The antioxidant power of MEL was shown at this study. It has been determined that dose-dependent MEL administration decreases the total oxidant content by increasing the antioxidant power, and normalizes the epileptic seizures and the metabolic changes that occur. This has revealed that MEL use is an effective substance that can be used to eliminate direct or indirect negative effects that may arise due to epileptic seizure processes in the long term.

\section{Ethics}

Ethics CommitteeApproval:Allanimalexperiments were carried out in accordance with the approval of the Animal Use Adnan Menderes University Ethical Committee (decision no: 64583101/2014/022, date: 27.02.2014).

Informed Consent: An animal experiment.

Peer-review: Externally peer-reviwed.

\section{Authorship Contributions}

Concept: F.Ş., R.O.E., Design: F.Ş., R.O.E., Supervision: F.Ş., R.O.E., Fundings: F.Ş., R.O.E., Materials: F.Ş., R.O.E., Data Collection or Processing: F.Ş., R.O.E., Analysis or Interpretation: F.S.,, R.O.E., Literature Search: F.Ş., R.O.E., Writing: F.Ş., R.O.E., Critical Review: F.S., R.O.E.

Conflict of Interest: No conflict of interest was declared by the authors.

Financial Disclosure: The authors declared that this study received no financial support.

\section{References}

1. Robinson SJ. Childhood epilepsy and autism spectrum disorders: psychiatric problems, phenotypic expression, and anticonvulsants. Neuropsychol Rev 2012; 22: 271-9.

2. Ma Y, Sun X, Li J, Jia R, Yuan F, Wei D, et al. Melatonin Alleviates the Epilepsy-Associated Impairments in Hippocampal LTP and Spatial Learning Through Rescue of Surface GluR2 Expression at Hippocampal CA1 Synapses. Neurochem Res 2017; 42: 1438-48.
3. Sander JW. The epidemiology of epilepsy revisited. Curr Opin Neurol 2003; 16: 165-70.

4. Mosińska P, Socała K, Nieoczym D, Laudon M, Storr M, Fichna $J$, et al. Anticonvulsant activity of melatonin, but not melatonin receptor agonists Neu-P11 and Neu-P67, in mice. Behav Brain Res 2016; 307: 199-207.

5. Gupta YK, Gupta M, Kohli K. Neuroprotective role of melatonin in oxidative stress vulnerable brain. Indian J Physiol Pharmacol 2003; 47: 373-86.

6. Frantz AL, Regner GG, Pflüger P, Coelho VR, da Silva LL, Viau CM, et al. Manual acupuncture improves parameters associated with oxidative stress and inflammation in PTZ-induced kindling in mice. Neurosci Lett 2017; 661: 33-40.

7. Bambal G, Çakıl D, Ekici F. Models of experimental epilepsy. J Clin Exp Invest 2011; 2: 118-23.

8. Löscher $W$, Hönack $D$, Fassbender $C P$, Nolting $B$. The role of technical, biological and pharmacological factors in the laboratory evaluation of anticonvulsant drugs. III. Pentylenetetrazole seizure models. Epilepsy Res 1991; 8: 171-89.

9. André V, Pineau N, Motte JE, Marescaux C, Nehlig A. Mapping of neuronal networks underlying generalized seizures induced by increasing doses of pentylenetetrazol in the immature and adult rat: a c-Fos immunohistochemical study. Eur J Neurosci 1998; 10: 2094-106.

10. Nasir SA, Sharma A, Khanam R, Vohora D. Effect of medroxyprogesterone on development of pentylenetetrazoleinduced kindling in mice. Neuroscience 2012; 207: 283-7.

11. Bonnefont-Rousselot D, Collin F. Melatonin: action as antioxidant and potential applications in human disease and aging. Toxicology 2010; 278: 55-67.

12. Yamamoto H, Tang HW. Preventive effect of melatonin against cyanide-induced seizures and lipid peroxidation in mice. Neurosci Lett 1996; 207: 89-92.

13. Mevissen $M$, Ebert $U$. Anticonvulsant effects of melatonin in amygdala-kindled rats. Neurosci Lett 1998; 257: 13-6.

14. Borowicz KK, Kamiński R, Gasior M, Kleinrok Z, Czuczwar SJ. Influence of melatonin upon the protective action of conventional anti-epileptic drugs against maximal electroshock in mice. Eur Neuropsychopharmacol 1999; 9: 185-90.

15. Uyanikgil Y, Özkeşkek K, Çavuşoğlu T, Solmaz V, Tümer MK, Erbas O. Positive effects of ceftriaxone on pentylenetetrazol-induced convulsion model in rats. Int J Neurosci 2016; 126: 70-5.

16. Yeleswaram K, McLaughlin LG, Knipe JO, Schabdach D. Pharmacokinetics and oral bioavailability of exogenous melatonin in preclinical animal models and clinical implications. J Pineal Res 1997; 22: 45-51.

17. Ying SW, Rusak B, Delagrange P, Mocaer E, Renard P, GuardiolaLemaitre $B$. Melatonin analogues as agonists and antagonists in the circadian system and other brain areas. Eur J Pharmacol 1996; 296: 33-42.

18. Racine RJ. Modification of seizure activity by electrical stimulation. II. Motor seizure. Electroencephalogr Clin Neurophysiol 1972; 32: 281-94. 
19. Pellow S, Chopin P, File SE, Briley M. Validation of open:closed arm entries in an elevated plus-maze as a measure of anxiety in the rat. J Neurosci Methods 1985; 14: 149-67.

20. Walf AA, Frye CA. The use of the elevated plus maze as an assay of anxiety-related behavior in rodents. Nat Protoc 2007; 2: 3228.

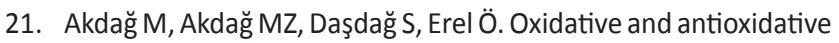
responses in submandibular and parotid glands of rats exposed to long-term extremely low frequency magnetic field. J Clin Exp Invest 2014; 5: 219-25.

22. Demougeot C, Marie C, Beley A. Importance of iron location in iron-induced hydroxyl radical production by brain slices. Life Sci 2000; 67: 399-410.

23. Sun Y, Oberley LW, Li Y. A simple method for clinical assay of superoxide dismutase. Clin Chem 1988; 34: 497-500.

24. Maehly AC, Chance B. The assay of catalases and peroxidases. Methods Biochem Anal 1954; 1: 357-424.

25. Hoffman GE, Moore N, Fiskum G, Murphy AZ. Ovarian steroid modulation of seizure severity and hippocampal cell death after kainic acid treatment. Exp Neurol 2003; 182: 124-34.

26. McIntyre DC, Racine RJ. Kindling mechanisms: current progress on an experimental epilepsy model. Prog Neurobiol 1986; 27: 1-12.

27. Schwartzkroin PA. (Ed.). Epilepsy: models, mechanisms and concepts. 1st Edition. Cambridge University Press 2007.

28. Wada T, Fukuda N. Effects of DN-2327, a new anxiolytic, diazepam and buspirone on exploratory activity of the rat in an elevated plus-maze. Psychopharmacology (Berl) 1991; 104: 444-50.

29. Yildirim M, Marangoz C. Anticonvulsant effects of melatonin on penicillin-induced epileptiform activity in rats. Brain Res 2006; 1099: 183-8.

30. Petkova Z, Tchekalarova J, Pechlivanova D, Moyanova S, Kortenska L, Mitreva R, et al. Treatment with melatonin after status epilepticus attenuates seizure activity and neuronal damage but does not prevent the disturbance in diurnal rhythms and behavioral alterations in spontaneously hypertensive rats in kainate model of temporal lobe epilepsy. Epilepsy Behav 2014; 31: 198-208.

31. Choopankareh S, Vafaee F, Shafei MN, Sadeghnia HR, Salarinia $\mathrm{R}$, Zarepoor $\mathrm{L}$, et al. Effects of melatonin and theanine administration on pentylenetetrazole-induced seizures and brain tissue oxidative damage in ovariectomized rats. Turk J Med Sci 2015; 45: 842-9.

32. Rodrigues AD, Scheffel TB, Scola G, Santos MT, Fank B, de Freitas $\mathrm{SC}$, et al. Neuroprotective and anticonvulsant effects of organic and conventional purple grape juices on seizures in Wistar rats induced by pentylenetetrazole. Neurochem Int 2012; 60: 799805.

33. Reilly C, Agnew R, Neville BG. Depression and anxiety in childhood epilepsy: a review. Seizure 2011; 20: 589-97.

34. Bai J, Cederbaum Al. Mitochondrial catalase and oxidative injury. Biol Signals Recept 2001; 10: 189-99.

35. Sudha K, Rao AV, Rao A. Oxidative stress and antioxidants in epilepsy. Clin Chim Acta 2001; 303: 19-24.

36. Eun JP, Choi HY, Kwak YG. Proteomic analysis of human cerebral cortex in epileptic patients. Exp Mol Med 2004; 36: 185-91.

37. Chang SJ, Yu BC. Mitochondrial matters of the brain: mitochondrial dysfunction and oxidative status in epilepsy. J Bioenerg Biomembr 2010; 42: 457-9.

38. Devi PU, Manocha A, Vohora D. Seizures, antiepileptics, antioxidants and oxidative stress: an insight for researchers. Expert Opin Pharmacother 2008; 9: 3169-77.

39. Oruc S, Gönül Y, Tunay K, Oruc OA, Bozkurt MF, Karavelioğlu $E$, et al. The antioxidant and antiapoptotic effects of crocin pretreatment on global cerebral ischemia reperfusion injury induced by four vessels occlusion in rats. Life Sci 2016; 154: 7986.

40. Koksal M, Oğuz E, Baba F, Eren MA, Ciftci H, Demir ME, et al. Effects of melatonin on testis histology, oxidative stress and spermatogenesis after experimental testis ischemia-reperfusion in rats. Eur Rev Med Pharmacol Sci 2012; 16: 582-8. 